\title{
UPREGULATION OF NEUROGLOBIN PROMOTES TM3 LEYDIG CELL VIABILITY
}

\author{
Ayşegül DOĞAN \\ Department of Genetics and Bioengineering, Faculty of Engineering, Yeditepe University, İstanbul, TURKEY \\ ORCID ID: orcid.org/0000-0003-4160-2270, e-mail: aysegul.dogan@yeditepe.edu.tr \\ Cite this article as: \\ Doğan A. 2018. Upregulation of Neuroglobin Promotes TM3 Leydig Cell Viability. Trakya Univ J Nat Sci, 19(2): 115-120, DOI: 10.23902/trkjnat.393371
}

Received: 11 February 2018, Accepted: 26 June 2018, Online First: 08 July 2018, Published: 15 October 2018

\begin{abstract}
Neuroglobin (NGB) is a globin family member protein expressed in the nerve system and prevents oxidative stress and apoptosis induced death in neurons. The anti-oxidant role of NGB against oxidative stress and reactive oxygen species (ROS) brings up its promising protective role in other tissues. The overexpression of NGB in testosterone producing Leydig cells might be a solution to hypoxia related male infertility. In the current study, NGB was overexpressed in Leydig cells by using viral transduction methods and the cell proliferation, gene expression and anti-oxidant enzyme levels were analyzed. Upregulation of NGB increased anti-apoptotic Bcl-2, cell proliferation and anti-oxidant enzyme levels and decreased the expression of apoptotic genes BAX, p53 and caspase 3. In addition, NGB transduced cells proliferated and expressed less apoptotic genes after $\mathrm{H}_{2} \mathrm{O}_{2}$ exposure. In conclusion, NGB might be a target for androgen deficiency related male infertility and could be used in clinics in the future.
\end{abstract}

Key words: Neuroglobin, Leydig cell, oxidative stress, anti-oxidant enzymes, male fertility.

Özet: Globin ailesi proteinlerinden bir tanesi olan Neuroglobin (NGB) sinir sisteminde ifade edilmektedir ve oksidatif stres ve apoptoz kaynaklı nöron ölümünü engellemektedir. Oksidatif stres ve reaktif oksijen türlerine karşı gözlemlenen anti-oksidan aktivite, NGB'nin diğer dokulardaki potansiyel koruyucu rolünü gündeme getirmektedir. Testosteron üreten Leydig hücrelerinde NGB'nin fazla ifade edilmesi hipoksi ile ilişkili erkek infertilitesi için bir çözüm olabilecektir. Bu çalışmada, NGB proteinin viral aktarım metodu ile Leydig hücrelerinde aşırı ifade ettirilmiş ve hücre çoğalması, gen anlatımı ve anti-oksidan enzim seviyeleri analiz edilmiştir. Artan NGB, anti-apoptotik Bcl-2, hücre çoğalması ve anti-oksidan enzim seviyelerini arttırmış, BAX, p53 ve kaspaz 3 gibi apoptoz genlerinin ifadesini azaltmıştır. Ek olarak, $\mathrm{H}_{2} \mathrm{O}_{2}$ uygulaması sonrasında NGB aktarılan hücreler çoğalmış ve apoptotik genlerin ifadesi azalmıştır. Sonuç olarak, NGB androjen eksikliğine bağlı erkek infertilitesi için hedef olabilir ve gelecekte klinikte kullanılabilir.

\section{Introduction}

Neuroglobin (NGB) was identified as a vertebrate nerve globin in neural tissues by Burmester et al. (2000). The NGB protein consists of 150 amino acids and is similar to myoglobin structurally (Burmester et al. 2000, Dewilde et al. 2001). Expression of NGB is observed in central and peripheral nervous system and some endocrine tissues (Reuss et al. 2002, Burmester et al. 2000).

The neuroprotective activity of NGB through prevention of apoptosis and oxidative stress is well documented (Amri et al. 2017). NGB is able bind to $\mathrm{O}_{2}$, $\mathrm{CO}$ or NO and prevents oxidative stress (Dewilde et al. 2001). The potential pathways and regulatory roles of NGB are providing $\mathrm{O}_{2}$ supply, preventing reactive oxygen species (ROS) damage and hypoxia (Burmester \& Hankeln 2009). NGB acts as a respiratory protein with an $\mathrm{O}_{2}$ binding affinity which resembles to myoglobin oxygen-binding capacity (Hundahl et al. 2006). Localization of NGB in specific tissues and cellular regions that are metabolically active supports its $\mathrm{O}_{2}$ binding ability (Schmidt et al. 2003). Interaction of NGB with $\mathrm{O}_{2}$ enables the regulation of NGB expression in hypoxic conditions (Schmidt-Kastner et al. 2006). NGB acts as NO-dioxygenase when $\mathrm{O}_{2}$ levels are low and react with $\mathrm{NO}_{2}$ to form NO (Petersen et al. 2008). NGB expression in human cell cultures is not only triggered by hypoxia (Haines et al. 2012) but also induced by $\mathrm{H}_{2} \mathrm{O}_{2}$ (De Marinis et al. 2013) indicating the regulatory role in $\mathrm{O}_{2}$ metabolism. 17 $\beta$-estradiol (E2) induced NGB upregulation in neurons has been shown to be neuroprotective (De Marinis et al. 2013). Moreover, NGB was shown to translocate into mitochondria upon hormone and $\mathrm{H}_{2} \mathrm{O}_{2}$ stimulation and prevent cytochrome $\mathrm{C}$ release to help overcoming stress induced programmed cell death (De Marinis et al. 2013, Brittain et al. 2010). NGB overexpression in transgenic animals prevented heart and brain injury after ischemia or stroke indicating the tissue protective role of NGB after oxidative stress (Sun et al. 2003, Khan et al. 2006, Jin et al. 2010). Endogenous NGB in neural tissues exerted 
neuroprotective roles against oxidative stress indicating the possible protective role of NGB in neurodegenerative disorders (Ye et al. 2009, Fiocchetti et al. 2013).

The harmful effects of oxidative stress are not only observed in neural tissues but also disrupt functions in many tissues of the systems of the body one of which is the reproductive system. Oxidative stress induced DNA damage in sperm function is one of the most important reasons for male fertility (Bisht et al. 2017). In addition to spermatogenesis, Leydig cell steroidogenesis is also sensitive to oxidative stress. A number of internal and external factors, e.g. age, infection, diabetes, temperature, testis diseases, toxin exposure and hormonal changes cause ROS production in the testes leading to male fertility problems (Asadi et al. 2017). The antioxidant defense system in Leydig cells protects testicular tissue and provides appropriate testosterone production and sperm generation (Aitken \& Roman 2008). Leydig cells are the primary sources for testosterone production which is required for male reproduction. Therefore, identification of new protective mechanisms that control oxidative stress mechanisms in Leydig cells might be valuable for future therapeutic applications. Although large amounts of NGB were detected in the nervous system and brain, endocrine organs including testis and pituitary and adrenal glands also express NGB (Burmester et al. 2000, Reuss et al. 2002, Zhang et al. 2002). Because NGB is expressed in testis tissue, we hypothesized that overexpression of NGB might protect testis cells against stress. Protective activity of NGB against oxidative stress in tissues such as that of the nervous system where high amounts of localization are observed gave rise to the idea of potential protective effect of NGB in other tissues. In the current study, the protective role of NGB in TM3 mouse Leydig cells was evaluated by using a genetic manipulation approach.

\section{Materials and Methods}

\section{$\underline{\text { Cell line }}$}

TM3-Leydig cells \#CRL-1714 were purchased from ATCC (Rockville, MD). Cells were incubated in a humidified chamber at $37{ }^{\circ} \mathrm{C}$ and $5 \% \mathrm{CO}_{2}$ in $1: 1$ mixture of Ham's F12 medium and Dulbecco's Modified Eagle's Medium (Invitrogen, Gibco, UK) supplemented with 5\% horse serum, $2.5 \%$ fetal bovine serum (FBS, Invitrogen, Gibco, UK) and $1 \%$ Penicillin/Streptomycin/ Amphotericin (PSA, Invitrogen, Gibco, UK).

\section{Viral production}

The coding sequence of mouse NGB was ligated into pLenti-III-2A-GFP (Abm, Richmond, CA, USA, Fig. 1A). pLenti-III-2A-GFP was used as the control vector. Lenti viral vector stocks for pLenti-III-2A-GFP and pLenti-III-NGB-2A-GFP expressing vectors were produced by calcium phosphate transfection of 293T cells. pLenti-III-2A-GFP and pLenti-III-NGB-2A-GFP were transfected into 293T cells together with pCMVDR8.2DVPR (Addgene, Cambridge, MA, USA) and pMD2.G (VSVG, Addgene, Cambridge, MA, USA) for packaging and viral supernatants were collected at 24 , 48 and $72 \mathrm{~h}$ post-transfection (Fig. 1B). Lenti viral supernatants were filtered and concentrated by ultracentrifugation. HeLa cells were transfected for viral titer calculation and GFP positive cells were analyzed by flow cytometry (FACS Aria, Becton Dickinson, San Jose, CA). $4 \times 10^{4}$ transducing units $/ \mathrm{mL}$ was determined as titer of pLenti-III-2A-GFP and pLenti-III-NGB-2A-GFP vectors.

\section{A}

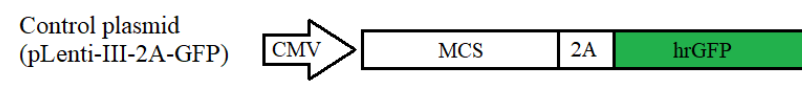
$\left.\begin{array}{l}\text { Neuroglobin plasmid } \\
\text { (pLenti-III-NGB-2A-GFP) }\end{array}\right)$ CMV $>$\begin{tabular}{|l|l|l|}
\hline NGB & 2A & hrGFP \\
\hline
\end{tabular}

$\mathrm{R}$

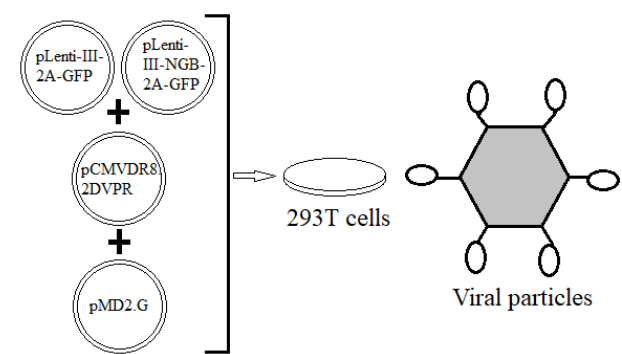

Fig. 1. Plasmid constructs and viral production method. (A) Structure of pLenti-III-2A-GFP and pLenti-III-NGB-2A-GFP vectors. (B) Packaging process of pLenti-III-2A-GFP and pLenti-III-NGB-2A-GFP vectors in 293T cells.

\section{Cell transduction}

TM3 cells were transduced with the viral supernatants of pLenti-III-2A-GFP and pLenti-III-NGBB-2A-GFP in the presence of $8 \mu \mathrm{g} / \mathrm{mL}$ of polybrene for $24 \mathrm{~h}$. GFP positive cells were sorted by flow cytometry and NGB overexpression was confirmed by qPCR analysis. Cell populations were referred as TM3-NGB and TM3-GFP for further experiments.

\section{Cell viability (MTS) analysis}

Cell viabilities of TM3-NGB and TM3-GFP cells and $\mathrm{H}_{2} \mathrm{O}_{2}$ applied TM3-NGB and TM3-GFP cells were measured by the 3-(4,5-di-methyl-thiazol- 2-yl)-5-(3carboxy-methoxy-phenyl)-2-(4-sulfo-phenyl)- 2Htetrazolium (MTS)-assay (CellTiter96 Aqueous One Solution; Promega, Southampton, UK) as described previously (Doğan et al. 2014). Briefly, 5x103 TM3-NGB and TM3-GFP cells were seeded onto 96-well plates and cell viability was measured by MTS assay for 24,48 , and 72 hours. Absorbances were measured at $490 \mathrm{~nm}$ by using an ELISA plate reader (Biotek, Winooski, VT).

\section{Determination of $\mathrm{H}_{2} \underline{\mathrm{O}}_{2}$ toxic dose}

TM3 Leydig cells were seeded onto 96-well plates at a cell density of 5000 cells/well. One day later, cells were treated with various concentrations $(100 \mu \mathrm{M}, 200 \mu \mathrm{M}$, $300 \mu \mathrm{M}, 400 \mu \mathrm{M})$ of $\mathrm{H}_{2} \mathrm{O}_{2}$ to determine the toxic dose for further experiments. Cell viability was measured by MTS assay and absorbance was measured at 490nm using an ELISA plate reader. 


\section{$\underline{\text { TUNEL assay }}$}

TdT-mediated dUTP nick-end labeling (TUNEL) assay was performed in TM3-NGB and TM3-GFP cells by using a TUNEL Assay kit (Roche Molecular Biochemicals, Indianapolis, IN) to detect the apoptotic cell number. Briefly, transduced cells were collected and suspended in $50 \mu 1$ of TUNEL reaction mixture (Labeling solution + Enzyme solution, supplied with the kit), incubated at $37^{\circ} \mathrm{C}$ and suspended in PBS for flow cytometry analysis using Becton Dickinson FACS Calibur (Becton Dickinson, San Jose, CA) flow cytometry system.

\section{Gene expression analyses}

Quantitative RT-PCR experiments were conducted according to the previously described protocol (Apdik et al. 2015). Primer sequences for NGB, p53, caspase3, Akt, BAX, Bcl-2 and $\beta$-actin were designed by IDT primer Quest software. $\beta$-Actin was used as housekeeping gene for normalization of the data. Total RNA was isolated form transduced cells and $\mathrm{H}_{2} \mathrm{O}_{2}$ administered cells by using a RNA-easy plus mini kit (Qiagen, Hilden, Germany) and cDNA was synthesized using High Fidelity cDNA synthesis kit (Roche, USA). qPCR experiments were conducted by SYBR Green using the CFX96 RT-PCR system (Bio-Rad, Hercules, CA).

\section{$\underline{\text { SOD and GPX activity measurements }}$}

SOD (19160, Sigma, MO, USA) and GPx (CGP1, Sigma, MO, USA) enzyme activities were determined in TM3-NGB and TM3-GFP cells according to the manufacturer's instructions. Protein samples were isolated from TM3-NGB and TM3-GFP cells by RIPA buffer and used for enzyme activity analysis. Absorbances of SOD and GPx assays were measured at 450nm and $340 \mathrm{~nm}$, respectively by using an ELISA plate reader.

\section{$\underline{\text { Statistical analysis }}$}

Results are expressed as mean \pm standard deviation. Standard errors and t-test values were calculated using the GraphPad Prism 5 (GraphPad, La Jolla, CA) software. Differences were considered to be statistically significant at $\mathrm{P}$ values of less than $0.05(\mathrm{P}<0.05)$.

\section{Results}

\section{Cell transduction and proliferation analysis}

TM3 cells were successfully transduced by pLenti-III2A-GFP and pLenti-III-NGB-2A-GFP lentiviral vectors. pLenti-III-2A-GFP transduction was conducted as control of viral transduction. GFP expressing cells were visualized by a fluorescence microscope (Fig. 2A). NGB expression was approximately 10 fold higher in TM3NGB-GFP cells $(10 \pm 0.0197)$ compared to TM3-GFP $(1 \pm 0.0056)$ cells demonstrating the successful overexpression by lentiviral vectors (Fig. 2B). In order to determine the effect of NGB upregulation on cell proliferation, MTS analyses were performed. Cell proliferation of TM3-NGB-GFP cells was significantly higher for 24, 48 and $72 \mathrm{~h}$ compared to TM3-GFP cells (Fig. 2C). Although absorbance values for TM3-GFP at $490 \mathrm{~nm}$ were $0.290 \pm 0.0051, \quad 0.350 \pm 0.0167$ and $0.410 \pm 0.0197$; absorbances of TM3-NGB-GFP were $0.367 \pm 0.0201,0.520 \pm 0.0198$ and $0.630 \pm 0.0265$ for day 1 , day 2 and day 3 respectively.

\section{TUNEL assay}

The apoptotic status of NGB overexpressing cells were detected by TUNEL assay. Although $27 \%$ of the TM3-GFP cells were apoptotic after transduction, only $12 \%$ of the TM3-NGB-GFP cells were positively stained (Fig. 2D).
A
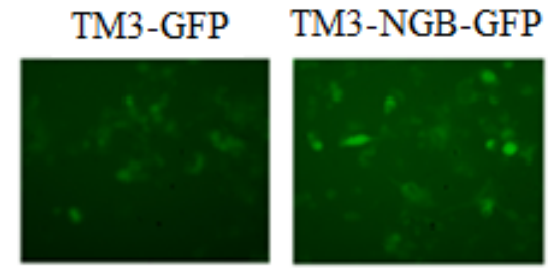

B

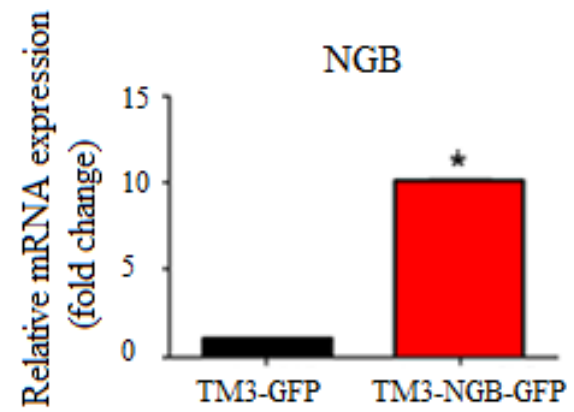

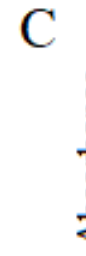

$\mathrm{D}$
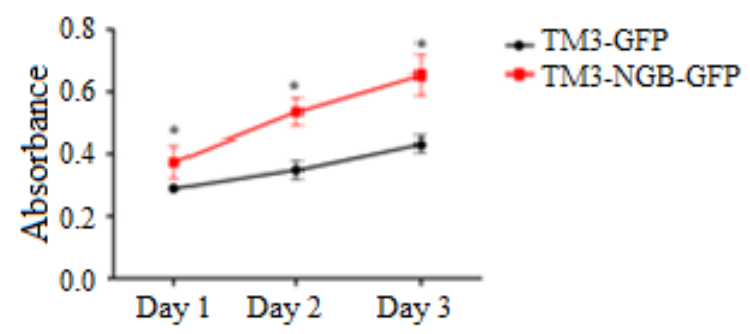

TM3-GFP

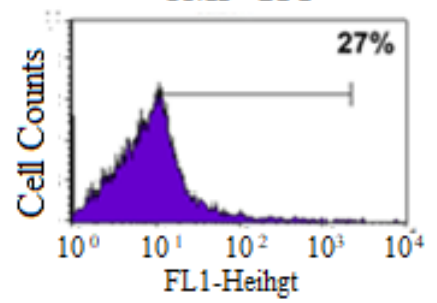

TM3-NGB-GFP

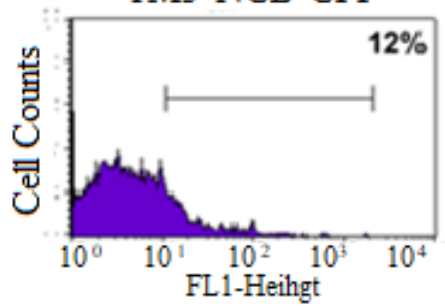

Fig. 2. Transduction of TM3 cells with pLenti-III-2A-GFP and pLenti-III-NGB-2A-GFP vectors and viability analysis. (A) Successful transduction of TM3 cells. Cells were GFP positive under fluorescence microscope indicating the viral transduction. (B) Confirmation of overexpression of NGB by qPCR analysis. (C) Cell proliferation of TM3-NGB-GFP and TM3-GFP cells. (D) TUNEL staining of TM3-NGB-GFP and TM3-GFP cells. *P $<0.05$. 


\section{Gene expression analyses}

Pro-apoptotic and anti-apoptotic gene expression levels were detected in NGB overexpressing TM3 cells. The apoptotic genes BAX, Caspase-3 and p53 were downregulated in TM3-NGB-GFP indicating the protective role of NGB in TM3 cells. Bcl-2 as an antiapoptotic gene was upregulated in NGB overexpressing TM3 cells (Fig. 3). The expression in TM3-NGB-GFP expressed almost 2-fold higher Bcl-2 (1.964 \pm 0.0298$)$ compared to TM3-GFP $(1 \pm 0.1390)$. BAX expression was not significantly different in TM3-NGB-GFP $(0.764 \pm 0.0299)$ and TM3-GFP $(1 \pm 0.1470)$ cells. Caspase3 and p53 were downregulated in TM3-NGB-GFP $(0.56 \pm 0.0210$ and $0.58 \pm 0.0231)$ compared to GFP expressing TM3 cell line.

\section{Protective role of $\mathrm{NGB}$ against $\mathrm{H}_{2} \underline{\mathrm{O}}_{2}$ toxicity}

Four different doses $(100 \mu \mathrm{M}, 200 \mu \mathrm{M}, 300 \mu \mathrm{M}, 400$ $\mu \mathrm{M})$ of $\mathrm{H}_{2} \mathrm{O}_{2}$ were applied to determine the toxic concentration for cell viability and qPCR analysis. Significant toxicity was observed starting from $200 \mu \mathrm{M}$ $\mathrm{H}_{2} \mathrm{O}_{2}(0.164 \pm 0.0080)$ compared to the control group (0.669 \pm 0.0205$) .200 \mu \mathrm{M} \mathrm{H}_{2} \mathrm{O}_{2}$ significantly reduced cell viability and was selected for further analysis (Fig. 4A). TM3-NGB-GFP cell viability was higher compared to TM3-GFP cells for 24,48 and $72 \mathrm{~h}$. The cell viability showed a time dependent increase in TM3-NGB-GFP cells for 3 days and was 2 fold higher compared to TM3GFP by day 3 (TM3-NGB-GFP: $0.205 \pm 0.0148$, TM3GFP: $0.093 \pm 0.0265$ ) (Fig. 4B). BAX, Caspase-3 and p53 genes were downregulated in TM3-NGB-GFP indicating the protective role of NGB in of TM3-NGB-GFP for p53, BAX, Bcl-2 and Caspase-3 were detected as $0.864 \pm 0.0299, \quad 0.800 \pm 0.0100, \quad 1.100 \pm 0.0300 \quad$ and
$0.812 \pm 0.0400$, respectively and no statistically significant difference was measured for these values (Fig. 4C).

\section{$\underline{\text { SOD and GPx enzyme activity }}$}

Potential role of NGB overexpression on antioxidant enzyme activities was detected by SOD and GPx activity measurements. NGB overexpression increased the antioxidant enzyme activities significantly compared to TM3-GFP cells. TM3-NGB-GFP cells exerted approximately 2 fold higher antioxidant enzyme activity. SOD and GPx enzyme activities of TM3-GFP cells were determined as $60 \% \pm 3.1$ and $57 \% \pm 3.2$, respectively while activities of both were $100 \%$ in TM3-NGB-GFP cells (Fig. 5).
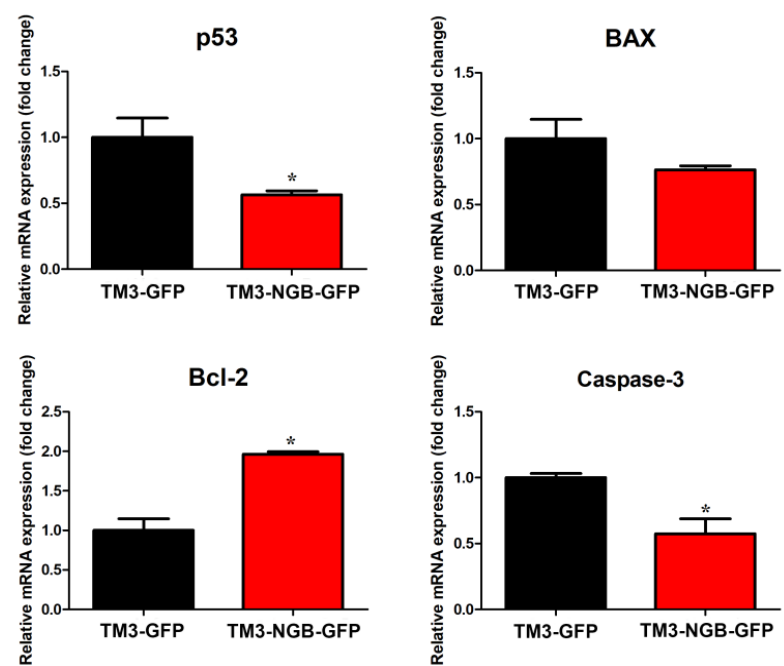

Fig. 3. Gene expression analysis of TM3-NGB-GFP and TM3GFP cells for pro- and anti-apoptotic genes. $* \mathrm{P}<0.05$.
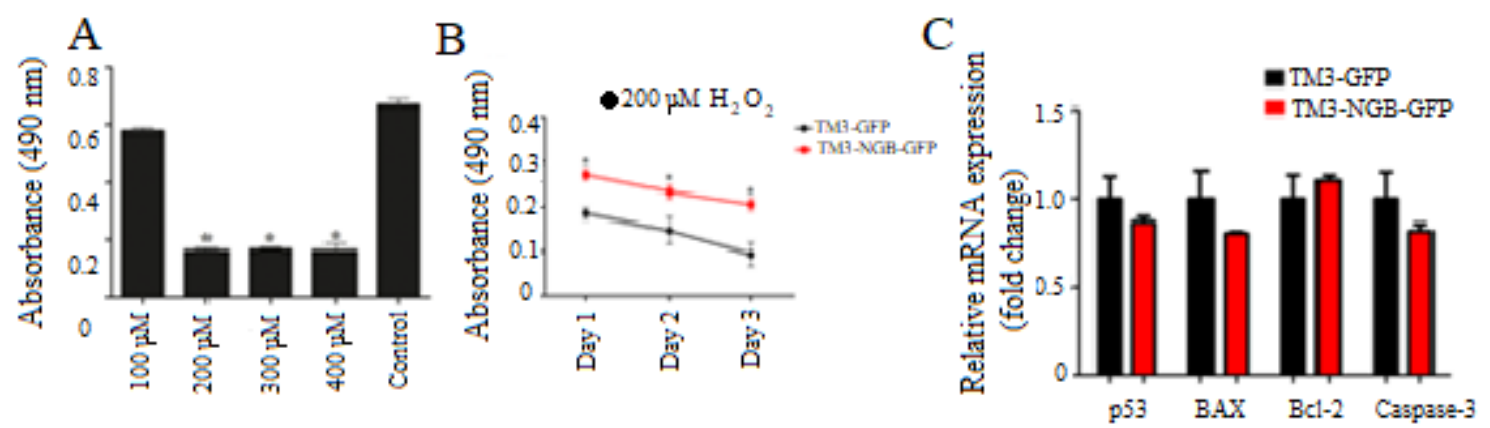

Fig. 4. Protective role of NGB against $\mathrm{H}_{2} \mathrm{O}_{2}$ stress. (A) Determination of $\mathrm{H}_{2} \mathrm{O}_{2}$ toxic dose based on cell viability. (B) Cell proliferation of TM3-NGB-GFP and TM3-GFP cells after $200 \mu \mathrm{M} \mathrm{H} \mathrm{H}_{2} \mathrm{O}_{2}$ exposure. (C) Expression levels of pro- and anti-apoptotic genes in TM3NGB-GFP and TM3-GFP cells after $200 \mu \mathrm{M} \mathrm{H}_{2} \mathrm{O}_{2}$ exposure. $* \mathrm{P}<0.05$.
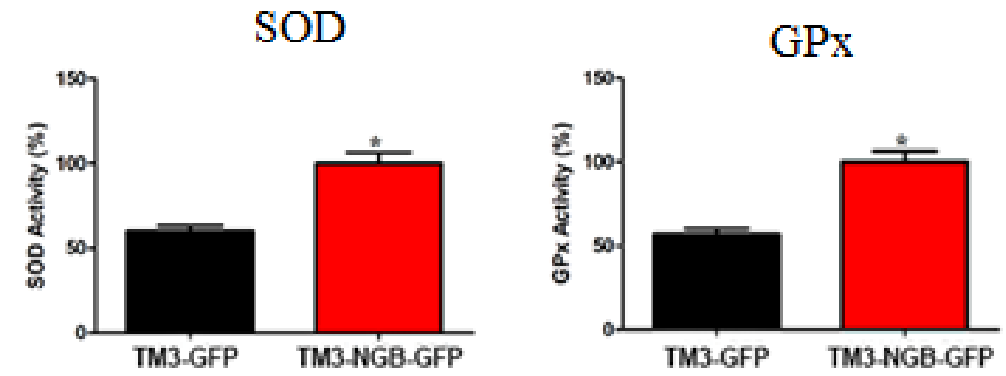

Fig. 5. SOD and GPx enzyme levels in TM3-NGB-GFP and TM3-GFP cells. $* \mathrm{P}<0.05$. 


\section{Discussion}

Free radicals generated through cellular metabolism cause oxidative stress in tissues such as testis and induce cell death. Oxidative stress induced ROS disrupts reproductive system, prevents androgen (testosterone) secretion and spermatogenesis (Aitken et al. 2008). Leydig cell dysfunction due to membrane lipid peroxidation upon Lipopolysaccharide (LPS) application has been observed previously (Husain \& Somani 1998). As Leydig cells produce androgens such as testosterone which binds to the androgen receptor and activates sperm generation (Dohle et al. 2003), they are potential targets for oxidative stress related male fertility treatments. Understanding the protective mechanisms against oxidative stress and identifications of new potential pathways are among the recent aims of studies addressing development of new therapeutic targets.

In the present study, we evaluated the role of NGB in Leydig cells by using an overexpressing gene editing approach. Because NGB protects many tissues against oxidative stress and are expressed in testis tissue, overexpression of NGB in Leydig cells could be promising to prevent harmful effects of oxidative stress. Proliferation of NGB overexpressing mouse TM3 Leydig cells were higher compared to control cells indicating the potential protective activity. The activity of NGB on cell proliferation and protection has previously been shown in neurons and cancer cells (Fiocchetti et al. 2017, Greenberg et al. 2008, Zhang et al. 2018) which supports our results. NBG overexpressing transgenic mice can rescue under hypoxic stress and NGB induces neural protection in vitro against hypoxic injury (Greenberg et al. 2008). Overexpression of NGB increased cell viability in MCF-7 breast cancer cells against nutrient deprivation through an anti-apoptotic Bcl-2 expression (Fiocchetti et al. 2017). Similarly, both overexpression and knockdown of NGB in glioblastoma cells regulated the cell proliferation by activating the PI3K/AKT pathway (Zhang et al. 2018). Promoting activity of NGB in cell

\section{References}

1. Aitken, R.J. \& Roman, S.D. (2008). Antioxidant systems and oxidative stress in the testes. Oxidative Medicine and Cellular Longevity, 1: 15-24.

2. Amri, F., Ghouili, I., Amri, M., Carrier, A. \& MasmoudiKouki, O. (2017). Neuroglobin protects astroglial cells from hydrogen peroxide-induced oxidative stress and apoptotic cell death. Journal of Neurochemistry, 140: 151169.

3. Apdik, H., Doğan, A., Demirci, S., Aydın, S. \& Şahin F (2015). Dose-dependent effect of boric acid on myogenic differentiation of human adipose-derived stem cells (hADSCs). Biological Trace Element Research, 165: 123130.

4. Asadi, N., Bahmani, M., Kheradmand, A. \& RafieianKopaei, M. (2017). The impact of oxidative stress on testicular function and the role of antioxidants in improving it: A review. Journal of Clinical and Diagnostic Research: JCDR, 11: IE01. proliferation and viability might be useful to increase Leydig cell number and to treat oxidative stress related male fertility in the future clinical applications. Additionally, low levels of TUNEL positive cells in NGB transduced cells demonstrated the anti-apoptotic role of NGB in Leydig cells. Knockdown of NGB in neurons increased TUNEL positive cells in arsenite induce toxicity indicating the protective role of NGB against apoptosis (Liu et al. 2015). Anti-apoptotic activity was confirmed by gene expression analysis of pro- and antiapoptotic genes including BAX, p53, caspase-3 and Bcl2. Enhanced Bcl-2 and low levels of BAX and caspase-3 have been reported after spinal cord injury in NGB overexpressing animals (Lan et al. 2014). Because Leydig cells are responsible for testosterone production and highly crucial for spermatogenesis, anti-apoptotic function of NGB to block apoptosis is highly important for potential therapeutic options. Same observations for cell proliferation and gene expression were reported after $\mathrm{H}_{2} \mathrm{O}_{2}$ exposure indicating the protective effect against ROS and oxidative stress. Induction of SOD and GPx in testis tissue (Kaur et al. 2006) and Leydig cells (Baek et al. 2007) is a defense mechanism after oxidative stress. Therefore, we evaluated the effect of NGB overexpression on anti-oxidant enzyme activities. NGB overexpression upregulated the SOD and GPx levels as reported in the literature. Although there is not an evidence in the literature for NGB overexpression in Leydig cells, transgenic mice overexpressing NGB showed high SOD and GPx levels in hippocampal tissues (Li et al. 2010).

In conclusion, we demonstrated, for the first time, the promising protective role of NGB in Leydig cells against oxidative stress. NGB gene could be a potential target for oxidative stress induced male infertility and might be used for therapy in future. Further experiments explaining the molecular mechanism of NGB in Leydig cells should be conducted both in vitro and in vivo.

5. Baek, I-J., Seo, D-S., Yon, J-M., Lee, S-R., Jin, Y., Nahm, SS., Jeong, J-H., Choo, Y-K., Kang, J-K. \& Lee, BJ. (2007). Tissue expression and cellular localization of phospholipid hydroperoxide glutathione peroxidase (PHGPx) mRNA in male mice. Journal of Molecular Histology, 38: 237-244.

6. Bisht, S., Faiq, M., Tolahunase, M. \& Dada, R. (2017). Oxidative stress and male infertility. Nature Reviews Urology, 14: 470.

7. Brittain, T., Skommer, J., Henty, K., Birch, N. \& Raychaudhuri, S. (2010). A role for human neuroglobin in apoptosis. IUBMB life, 62: 878-885.

8. Burmester, T. \& Hankeln, T. (2009). What is the function of neuroglobin? Journal of Experimental Biology, 212: 1423-1428.

9. Burmester, T., Weich, B., Reinhardt, S. \& Hankeln, T. (2000). A vertebrate globin expressed in the brain. Nature, 407: 520 . 
10. De Marinis, E., Fiocchetti, M., Acconcia, F., Ascenzi, P. \& Marino, M. (2013). Neuroglobin upregulation induced by $17 \beta$-estradiol sequesters cytocrome $\mathrm{c}$ in the mitochondria preventing $\mathrm{H}_{2} \mathrm{O}_{2}$-induced apoptosis of neuroblastoma cells. Cell Death \& Disease, 4: e508.

11. Dewilde, S., Kiger, L., Burmester, T., Hankeln, T., BaudinCreuza, V., Aerts, T., Marden, M.C., Caubergs, R. \& Moens, L. (2001). Biochemical characterization and ligand binding properties of neuroglobin, a novel member of the globin family. Journal of Biological Chemistry, 276: 38949-38955.

12. Doğan, A., Demirci, S., Çağlayan, A.B., Kılıç, E., Günal, M.Y., Uslu, Ü., Cumbul, A. \& Şahin, F. (2014). Sodium pentaborate pentahydrate and pluronic containing hydrogel increases cutaneous wound healing in vitro and in vivo. Biological Trace Element Research, 162: 72-79.

13. Dohle, G., Smit, M. \& Weber, R. (2003). Androgens and male fertility. World Journal of Urology, 21: 341-345.

14. Fiocchetti, M., Cipolletti, M. \& Marino, M. (2017). Compensatory role of Neuroglobin in nervous and nonnervous cancer cells in response to the nutrient deprivation. PloS One, 12: e0189179.

15. Fiocchetti, M., De Marinis, E., Ascenzi, P. \& Marino, M. (2013). Neuroglobin and neuronal cell survival. Biochimica et Biophysica Acta (BBA)-Proteins and Proteomics, 1834: 1744-1749.

16. Greenberg, D.A., Jin, K. \& Khan, A.A. (2008). Neuroglobin: an endogenous neuroprotectant. Current Opinion in Pharmacology, 8: 20-24.

17. Haines, B., Demaria, M., Mao, X., Xie, L., Campisi, J., Jin, K. \& Greenberg, D.A. (2012). Hypoxia-inducible factor-1 and neuroglobin expression. Neuroscience Letters, 514: 137-140.

18. Hundahl, C., Fago, A., Dewilde, S., Moens, L., Hankeln, T., Burmester, T. \& Weber, R.E. (2006). Oxygen binding properties of non-mammalian nerve globins. The FEBS Journal, 273: 1323-1329.

19. Husain, K. \& Somani, S. (1998). Interaction of exercise training and chronic ethanol ingestion on testicular antioxidant system in rat. Journal of Applied Toxicology, 18: 421-429.

20. Jin, K., Mao, Y., Mao, X., Xie, L. \& Greenberg, D.A. (2010). Neuroglobin expression in ischemic stroke. Stroke, 41: 557-559.

21. Kaur, P., Kaur, G. \& Bansal, M.P. (2006). Tertiary-butyl hydroperoxide induced oxidative stress and male reproductive activity in mice: role of transcription factor $\mathrm{NF}-\mathrm{\kappa B}$ and testicular antioxidant enzymes. Reproductive Toxicology, 22: 479-484.

22. Khan, A.A., Wang, Y., Sun, Y., Mao, X.O., Xie, L., Miles, E., Graboski, J., Chen, S., Ellerby, L.M. \& Jin, K. (2006). Neuroglobin-overexpressing transgenic mice are resistant to cerebral and myocardial ischemia. Proceedings of the National Academy of Sciences, 103: 17944-17948.

23. Lan, W-B., Lin, J-H., Chen, X-W., Wu, C-Y., Zhong, GX., Zhang, L-Q., Lin, W-P., Liu, W-N., Li, X. \& Lin, J-L. (2014). Overexpressing neuroglobin improves functional recovery by inhibiting neuronal apoptosis after spinal cord injury. Brain Research, 1562: 100-108.

24. Li, R.C., Guo, S.Z., Lee, S.K. \& Gozal, D. (2010). Neuroglobin protects neurons against oxidative stress in global ischemia. Journal of Cerebral Blood Flow \& Metabolism, 30: 1874-1882.

25. Liu, X., Gao, Y., An, Y., Fu, X., Li, Y., Sun, D. \& Wang, J. (2015). Neuroglobin plays a protective role in arseniteinduced cytotoxicity by inhibition of CDC42 and raclgtpases in rat cerebellar granule neurons. Cellular Physiology and Biochemistry, 36: 1613-1627.

26. Petersen, M.G., Dewilde, S. \& Fago, A. (2008). Reactions of ferrous neuroglobin and cytoglobin with nitrite under anaerobic conditions. Journal of Inorganic Biochemistry, 102: 1777-1782.

27. Reuss, S., Saaler-Reinhardt, S., Weich, B., Wystub, S., Reuss, M., Burmester, T. \& Hankeln, T. (2002). Expression analysis of neuroglobin mRNA in rodent tissues. Neuroscience, 115: 645-656.

28. Schmidt-Kastner, R., Haberkamp, M., Schmitz, C., Hankeln, T. \& Burmester, T. (2006). Neuroglobin mRNA expression after transient global brain ischemia and prolonged hypoxia in cell culture. Brain Research, 1103: 173-180.

29. Schmidt, M., Giessl, A., Laufs, T., Hankeln, T., Wolfrum, U. \& Burmester, T. (2003). How does the eye breathe? Evidence for neuroglobin-mediated oxygen supply in the mammalian retina. Journal of Biological Chemistry, 278: 1932-1935.

30. Sun, Y., Jin, K., Peel, A., Mao, X.O., Xie, L. \& Greenberg, D.A. (2003). Neuroglobin protects the brain from experimental stroke in vivo. Proceedings of the National Academy of Sciences, 100: 3497-3500.

31. Ye, S-q., Zhou, X-y., Lai, X-j., Zheng, L. \& Chen, X-q. (2009). Silencing neuroglobin enhances neuronal vulnerability to oxidative injury by down-regulating 14-3$3 \gamma$. Acta Pharmacologica Sinica, 30: 913.

32. Zhang, B., Liu, Y., Li, Y., Zhe, X., Zhang, S. \& Zhang, L. (2018). Neuroglobin promotes the proliferation and suppresses the apoptosis of glioma cells by activating the PI3K/AKT pathway. Molecular Medicine Reports, 17: 2757-2763.

33. Zhang, C., Wang, C., Deng, M., Li, L., Wang, H., Fan, M., Xu, W., Meng, F., Qian, L. \& He, F. (2002). Full-length cDNA cloning of human neuroglobin and tissue expression of rat neuroglobin. Biochemical and Biophysical Research Communications, 290: 1411-1419. 